\title{
Effect of meterological factors on the composition of aerial mycobiota over local agricultural fields in mansehra
}

\begin{abstract}
The study of aerial mycobiota over agricultural fields could be very helpful in forecasting of plant diseases in a specific area and season. The present study was carried out to isolate the aerial mycobiota over four agricultural fields of Mansehra throughout the year. The qualitative and quantitative analysis of the composition of aerial mycobiota during different seasons revealed a well marked variations in the composition and number of different phytopathogenic fungal species. The spores of different phytopathogenic fungi showed seasonal occurrence and also related to the particular crops. Twenty four fungal spores were isolated and identified under various metrological factors. The species of Alternaria, Aspergillus, Cladosporium, Helminthosporium, Fusarium, Mucor, Rhizopus, Rhizoctonia, and Penicillium were dominant. The results of present study could be very helpful to understand the impact of various environmental factors on local crops and also to make strategies against phytopathogens in different prevailing conditions.
\end{abstract}

Volume 4 Issue 3 - 2017

Muhammad Farooq
Department of Microbiology, University of Swabi, Pakistan

Correspondence: Muhammad Farooq, Department of Microbiology, University of Swabi, Pakistan, Emailmfarooq@uoswabi.edu.pk

Received: July 30, 2016 | Published: March 20, 2017

Keywords: phytopathogens, environment, aerial mycobiota, mansehra

\section{Introduction}

The air is always contaminated with a number of microspores of different origin and can be isolated from all types of indoors and outdoors environments. ${ }^{1}$ The spores can contaminate all types of materials under favorable climatic and environmental conditions. Under prevailing climatic conditions these spores become a potent threat for their host plants and cause many seasonal diseases. ${ }^{2}$ Seasonal variations in climatic conditions are therefore responsible not only for variations in the number and types of fungal spores. It has been observed that air mostly contaminated with high spore contents during summer due to high temperature and humidity. ${ }^{3}$ Fungal spores in air are mostly different in their concentration and diversity due to many factors. In the dissemination of many plant diseases, airborne fungal spores are of prime importance. ${ }^{4}$ They cause serious agricultural problems and sometime result in epidemics. ${ }^{5}$

Many airborne fungal diseases like rust, powdery mildew, leaf spots, anthracnose and blight are very common in many parts of the world. ${ }^{6}$ The fungal spores that are usually associated with plant diseases always have high concentration of their spores in air before appearances of symptoms. ${ }^{7}$ The results of different studies on phytopathogens showed that high moisture and moderate temperatures favor the growth of fungi, while the spore germination is influenced by low relative humidity and high temperatures. ${ }^{6}$

Seasonal studies of aerial mycobiota of particular sites especially the agricultural fields could be very helpful in plant disease forecasting. Disease epidemiology and control could be better dealt with the proper information of aeromycoflora. ${ }^{8}$ The record of aerial mycobiota can be very helpful in establishing the forecasting probabilities of diseases and also the distribution of pathogenic microbes. The study of aeromycoflora of any field is significance along with epidemiology, population biology and disease prediction systems for the management of foliar pathogens. ${ }^{9}$

The present study was designed to understand the dissemination and spread of phytopathogens in the atmosphere of agricultural fields of Mansehra. This pathological study was designed to find any correlation between common plant diseases in these areas due to aerial mycobiota. The study was also designed to ascertain the relationship between air borne fungal spores and changing climatic and environmental conditions of Hazara division.

\section{Materials and methods}

\section{Experimental fields}

Present investigation was carried out in four selected agricultural fields located in Ahal, Shinkiari, Ichrian and Baffa. The aerial mycobiota was counted from January, 2014 to December, 2014. The crops sown in these fields were wheat, maize, soya bean, Mung bean, potatoes, tomatoes, cauliflower, potatoes, capsicum and different fodders.

\section{Isolation and identification of aerial mycobiota}

Aerial mycobiota was isolated by gravitation plate method. ${ }^{10}$ Potato dextrose agar and malt extract agar media were used for the trapping of air borne fungal spores. The streptomycin $(4 \mathrm{~g} / \mathrm{L})$ was used as antibacterial agent. Petri plates with three replications for each media were exposed in open atmosphere of selected fields for five minutes at about $1 \mathrm{~m}$ height. The survey of aerial mycobiota was carried out in first and last week of every month considering clear climatic conditions. After exposure the Petri plates were tightly sealed with Para film and brought to the laboratory. These plates were incubated at $25-30^{\circ} \mathrm{C}$ for seven days. ${ }^{11}$ The fungal colonies appeared in plates were observed under stereoscope. New plates were inoculated with individual fungal colony by loop method to obtain pure culture.

All the fungi isolated from air were identified on the bases of colony characters (color, texture, and size), microscopic features (size, shape, color and growth pattern of spores and hypha) using authentic literature. ${ }^{12,13}$ 


\section{Pure cultures}

Fungal cultures were maintained and preserved on PDA in mineral oil, and in sterilized distilled water in MeCauteny vials. ${ }^{14}$ These cultures were stored at $4^{\circ} \mathrm{C}$ for reference to be used in further research. Meteorological data Meteorological data of maximum, minimum and mean temperature, relative humidity, rain fall, wind speed and wind direction was recorded at Taxila during the whole potato season. Weekly means were calculated corresponding to weekly exposure of Petri dishes. It was correlated with the average number of colonies of airborne mycoflora.

\section{Results and discussion}

\section{Aerial mycobiota of selected sites}

During the present investigation 3355 fungal colonies were counted from the air of all selected sites from January 2014 to December, 2014. The aerial mycobiota of the four agricultural sites was comprised of 24 fungal species belonging to 17 different genera. The composition of aerial mycobiota is given in Table 1 .

\section{Predominant fungal species}

The fungal species counted during present study revealed that Alternaria solani with $11.50 \%$ of total colonies was the dominant fungal species followed by Alternaria alternata (8.34\%), Aspergillus niger $(7.60 \%)$, Rhizoctonia solani (7.12\%), Cladosporium herbarum (6.52\%), Aspergillus flavus (6.32\%), Rhizopus stolonifer (5.30\%), Rhizopus oryzae (5.09\%), Penicillium frequentans (5.0\%), Mucor hiemalis (4.97\%), Fusarium oxysporum (4.77\%), Cladosporium cladosporioides (4.74\%), Helminthosporium solani (4.68\%), Aspergillus fumigatus (4.59\%), Penicillium chrysogenum (4.20\%)and Alternaria brassicae (3.07\%). The other isolated fungal species were counted in low percentages as shown in Table 2.

\section{Site wise composition of aeromycoflora}

A well-marked variation in the composition of Aerial mycobiota of four selected agricultural fields was found in present study. Many fungal species were found restricted to a particular site.
The variation in the composition of air borne fungi isolated from selected fields is given in Table 3. Alternaria alternata, Alternaria solani, Aspergillus niger, Aspergillus flavus, Aspergillus fumigatus, Cladosporium herbarum, Fusarium oxysporum, Helminthosporium solani, Mucor hiemalis, Penicillium chrysogenum, Penicillium frequentans and Rhizopus oryzae were detected as common fungal species in the air of all selected fields.

Some variations in the composition of aeromycoflora of individual site were noticed in present investigation. These variations were found in the occurrence of some fungal species at particular sites only. The fungal species Acremonium, Cladosporium cladosporioides and Arthobotrytis were only isolated from Ahal, Shinkiari fields while Drechslera $s p$. was only found from Ahal. The fungal species Alternaria brassicae, Drechslera sp., Rhizopus Stolonifer, Trichocladium asperum and Curvularia lunata were totally absent from the air of Shinkiari. Similar variations were also found in other three selected fields.

\section{Seasonal variations in aerial mycobiota}

Many fungal species showed their seasonal occurrence in the air and total number of fungal colonies was also found variable in different months of the year. The air borne fungal species isolated from the four agricultural fields a well-marked seasonal variation as shown in Table 2. Some fungal species showed their occurrence in some specific months of the year. The fungal species of Alternaria alternata, Alternaria solani, Alternaria brassicae, Aspergillus fumigatus, Aspergillus niger, Aspergillus flavus, Cladosporium herbarum, Cladosporium cladosporioides, Fusarium oxysporum, Helminthosporium solani, Mucor hiemalis, Penicillium chrysogenum, Penicillium frequentans, Rhizopus stolonifer, Rhizopus oryzae and Rhizoctonia solani were found during all seasons as these fungi showed their presence in all sampling months.

Some fungal species showed their appearance in the air during specific months as Alternaria brassicae and Phoma glomerata were not found during December, January and February while Acremonium $s p$., Arthobotrytis sp. and Drechslera were found only in the months of December, January, February and March only. Aspergillus terrus and Trichothecium asperum were counted in July, August and September.

Table I Composition of aerial mycobiota of selected agricultural fields of Mansehra

\begin{tabular}{ll}
\hline Fungal Genera & Fungal Species \\
\hline Alternaria & Alternaria alternate, Aalternaria solani, Alternaria brassicae \\
Acremonium & Acremonium sp. \\
Arthobotrys & Arthobotrys sp. \\
Drechslera & Drechslera sp. \\
Aspergillus & Aspergillus niger, Aspergillus flavus, Aspergillus terrus, Aspergillus fumigatus \\
Cladosporium & Cladosporium herbarum, Cladosporium cladosporioides \\
Helminthosporium & Helminthosporium solani \\
Fusarium & Fusarium soani \\
Mucor & Mucor hiemalis \\
Rhizopus & Rhizopus oryzae, Rhizopus Stolonifer \\
Rhizoctonia & Rhizoctonia solani \\
Trichocladium & Trichocladium asperum \\
Curvularia & Curvularia lunata \\
Phoma & Phoma glomerata \\
Penicillium & Penicillium chrysogenum \\
Trichothecium & Penicillium sp. \\
Geotrichum & Geotrichum candidum \\
\hline
\end{tabular}


The highest number of colonies was found in September (501) followed by August (475), October (428), July (324), March (254), April (231), December (225), February (201), May (135) and January (118). The monthly colony counts of fungal species isolated from the air of selected sites revealed that the fungal colonies showed an increase from January to April then a decrease in May and June. An increase in the number of fungal colonies was again observed from July to October.

The fungal genera dominant in present study were also recorded in the findings of many researchers previously. The fungal genera Alternaria, Aspergillus, Fusarium, Penicillium, Rhizopus, Cladosporium and Helminthosporium were also found as prevalent components of aerial mycobiota in different parts of the world. ${ }^{15}$ During the study some plant diseases were also observed in selected fields. In shinkiari early blight stem canker and fruit rot of tomato were recorded. The air of this field contained Alternaria solani and Alternaria alternata with high concentration and throughout the year. The spores of Helminthosporium solani were counted in the air of Ahal before sowing of Mung bean and as expected the plants were found contaminated with this pathogen on ripening. In a same observation of aerial mycobiota of Ichrian Fusarium oxysporum was dominant in the area and found a cause of Fusarium wilt in capsicum in the selected field. These observations revealed that the presence of specific type of spores in air could cause particular disease if the host plat is grown there.

Table 2 Variations in isolated fungal species from selected fields

\begin{tabular}{|c|c|c|c|c|}
\hline Fungal Species & Ahal & Shinkiari & Ichrian & Baffa \\
\hline Alternaria alternata & + & + & + & + \\
\hline Aalternaria solani & + & + & + & + \\
\hline Alternaria brassicae & + & - & + & - \\
\hline Acremonium sp. & + & + & - & - \\
\hline Arthobotrys sp. & + & + & - & - \\
\hline Drechslera sp. & + & - & - & - \\
\hline Aspergillus niger & + & + & + & + \\
\hline Aspergillus flavus & + & + & + & + \\
\hline Aspergillus terrus & - & + & + & - \\
\hline Aspergillus fumigatus & + & + & + & + \\
\hline Cladosporium herbarum & + & + & + & + \\
\hline Cladosporium cladosporioides & + & + & - & - \\
\hline Helminthosporium solani & + & + & + & + \\
\hline Fusarium oxysporum & + & + & + & \\
\hline Mucor hiemalis & + & + & + & + \\
\hline Rhizopus oryzae & + & + & + & + \\
\hline Rhizopus Stolonifer & - & - & + & + \\
\hline Rhizoctonia solani & + & + & + & + \\
\hline Trichocladium asperum & - & - & + & + \\
\hline Curvularia lunata & + & - & - & + \\
\hline Phoma glomerata & + & + & + & - \\
\hline Penicillium chrysogenum & + & + & + & + \\
\hline Penicillium frequentans & - & + & + & - \\
\hline Geotrichum candidum & + & + & + & - \\
\hline
\end{tabular}

Table 3 Seasonal variations in aerial mycobiota during Jan-Dec, 2015

\begin{tabular}{|c|c|c|c|c|c|c|c|c|c|c|c|c|c|c|}
\hline Fungal Species & Jan & Feb & Mar & Apr & May & Jun & Jul & Aug & Sep & Oct & Nov & Dec & $\begin{array}{l}\text { Total } \\
\text { Colonies }\end{array}$ & $\begin{array}{l}\% \text { Of Total } \\
\text { Colonies }\end{array}$ \\
\hline Alternaria alternata & 15 & 12 & 17 & 20 & 8 & 5 & 34 & 38 & 49 & 31 & 28 & 23 & 280 & 8.34 \\
\hline Aalternaria solani & 19 & 15 & 21 & 27 & II & 9 & 43 & 58 & 64 & 48 & 39 & 32 & 386 & 11.5 \\
\hline Alternaria brassicae & 0 & 0 & 4 & 9 & 12 & 3 & 12 & 19 & 24 & 18 & 2 & 0 & 103 & 3.07 \\
\hline Acremonium sp. & 10 & 9 & 7 & 0 & 0 & 0 & 0 & 0 & 0 & 0 & 0 & 4 & 30 & 0.89 \\
\hline Arthobotrys sp. & 3 & 8 & 8 & 0 & 0 & 0 & 0 & 0 & 0 & 0 & 0 & 6 & 25 & 0.74 \\
\hline Drechslera sp. & 8 & 6 & 12 & 0 & 0 & 0 & 0 & 0 & 0 & 0 & 0 & 3 & 29 & 0.86 \\
\hline Aspergillus niger & 18 & 21 & 23 & 13 & 15 & 9 & 17 & 32 & 37 & $4 I$ & 19 & 10 & 255 & 7.6 \\
\hline Aspergillus flavus & 6 & II & 19 & 13 & 10 & 10 & 32 & 41 & 28 & 21 & 13 & 8 & 212 & 6.32 \\
\hline Aspergillus terrus & 0 & 0 & 0 & 0 & 0 & 0 & 4 & 6 & 8 & 0 & 0 & 0 & 18 & 0.53 \\
\hline Aspergillus fumigatus & II & 8 & 7 & 14 & 3 & 3 & 9 & 16 & 21 & 31 & 18 & 13 & 154 & 4.59 \\
\hline Cladosporium herbarum & 12 & 13 & 15 & 23 & 5 & 3 & 17 & 37 & 39 & 24 & 20 & II & 219 & 6.52 \\
\hline Cladosporium cladosporioides & 9 & II & 13 & 17 & 6 & 2 & 12 & 16 & 22 & 28 & 17 & 6 & 159 & 4.74 \\
\hline Helminthosporium solani & 4 & 8 & 15 & 9 & 7 & 8 & 19 & 35 & 25 & 16 & 7 & 4 & 157 & 4.68 \\
\hline Fusarium oxysporum & 6 & 9 & 17 & 8 & 11 & 17 & 24 & 31 & 17 & II & 6 & 3 & 160 & 4.77 \\
\hline Mucor hiemalis & 5 & 6 & 11 & 11 & 9 & 19 & 21 & 27 & 17 & 13 & 11 & 17 & 167 & 4.97 \\
\hline
\end{tabular}


Table Continued...

\begin{tabular}{|c|c|c|c|c|c|c|c|c|c|c|c|c|c|c|}
\hline Fungal Species & Jan & Feb & Mar & Apr & May & Jun & Jul & Aug & Sep & Oct & Nov & Dec & $\begin{array}{l}\text { Total } \\
\text { Colonies }\end{array}$ & $\begin{array}{l}\% \text { Of Total } \\
\text { Colonies }\end{array}$ \\
\hline Rhizopus oryzae & 12 & 15 & 18 & 21 & 6 & 8 & 13 & 15 & 17 & II & 16 & 19 & 171 & 5.09 \\
\hline Rhizopus Stolonifer & 10 & 9 & 8 & 6 & 4 & 6 & 18 & 29 & 36 & 32 & 12 & 8 & 178 & 5.3 \\
\hline Rhizoctonia solani & 12 & 16 & 21 & 25 & 10 & 8 & 16 & 25 & 31 & 36 & 21 & 18 & 239 & 7.12 \\
\hline Trichocladium asperum & 0 & 0 & 3 & 4 & 6 & 0 & 0 & 0 & 0 & 0 & 0 & 0 & 13 & 0.38 \\
\hline Curvularia lunata & 0 & 0 & 0 & 0 & 0 & 0 & 6 & 8 & 10 & 12 & 0 & 0 & 36 & $\mathrm{I} .07$ \\
\hline Phoma glomerata & 6 & 6 & 0 & 0 & 0 & 0 & 0 & 0 & 0 & 0 & 8 & 12 & 32 & 0.95 \\
\hline Penicillium chrysogenum & 10 & 8 & 6 & 5 & 5 & 4 & 14 & 17 & 21 & 22 & 17 & 12 & $14 \mid$ & 4.2 \\
\hline Penicillium frequentans & 12 & 10 & 8 & 6 & 7 & 5 & II & 18 & 27 & 28 & 20 & 16 & 168 & 5 \\
\hline Geotrichum candidum & 0 & 0 & 0 & 0 & 0 & 0 & 2 & 7 & 8 & 5 & 0 & 0 & 22 & 0.65 \\
\hline Total colonies & 118 & 201 & 253 & 231 & 135 & 119 & 324 & 475 & 501 & 428 & 274 & 225 & & \\
\hline Temperature ( oC ) Max & 17 & 14 & 23 & 25 & 34 & 36 & 32 & 30 & 31 & 28 & 24 & 20 & & \\
\hline Temperature ( oC ) Min & 2 & 3 & 8 & 10 & 15 & 19 & 19 & 20 & 17 & 10 & 5 & I & & \\
\hline Relative Humidity \% & 65 & 67 & 62 & 58 & 51 & 55 & 74 & 73 & 69 & 53 & 50 & 46 & & \\
\hline Rainfall mm & 28.6 & 308.8 & 78.6 & 43.1 & 61.8 & 67.9 & 409.6 & 413.7 & 52.3 & 9.72 & 4.43 & 21.83 & & \\
\hline
\end{tabular}

\section{Conclusion}

The results of present study clearly indicate the threat of fungal diseases in local crops due to the presence of many fungal pathogenic spores in the air over agricultural fields in Mansehra. The changing climatic condition in Mansehra is key factor for the incidence and high concentration of some specific fungal spores in air. Further comprehensive study is required to evaluate the seasonal occurrence of phytopathogens in air and their relation to crop rotation to avoid any fungal based disease outbreak in this area.

\section{Conflicts of Interest}

The authors declare no conflict of interest.

\section{Acknowledgments}

None.

\section{Funding}

None.

\section{References}

1. Medrela Kuder E. Analiza porownawcza zanieczyszczenia mikologicznego powietrza atmosferycznego i powietrza mieszkan prawidlowo eksploatowanych. Materialy Krajowej Konferencji, Zdrowy Dom, Warszawa, Poland. 2001; p. 182-184.

2. Medrela Kuder E. Mycological air pollution at sites of heavy traJc in Cracow. Acta Biologica Cracoviensia. 2000;42: 21-24.

3. Bandyopadhyay R, Mughogho LK, Satyanarayana MV. Occurrence of airborne spores of fungi causing grain mould over a sorghum crop. Mycol Res. 1991;95(11):1315-1320.
4. McCartney HA. Airborne dissemination of plant fungal pathogens. J Appl Bacteriol Symp. 1991. p. 7039-7048.

5. Hirst JM. Aerobiology in plant pathology. Grana. 1991;30(1):25-29.

6. Rowan NJ, Johnstone, CM, McLean RC, et al. Prediction of toxigenic fungal growth in buildings by using a novel modelling system. Appl Environ Microbiol. 1999;65(11):4814-4821.

7. Kumar R. Aerospora in pine forest in India. Grana. 1982;21(3):179-181.

8. Ponti I, Cavani P. Aerobiology in plant protection. Aerobiologia. 1992; 8(1):94-101.

9. Cook RJ. Advances in plant health management in the twentieth century. Annu Rev Phytopathol. 2000;38: 95-116.

10. Uddin N. Airspora studies over a rice (high yielding variety) field in rabi season in the state of West Bengal, India. Aerobiologia. 2004;20(2):127134

11. Talley SM, Phyllis DC, Thomas AK. The effects of weather on fungal abundance and richness among 25 communities in the Intermountain West. BMC Ecol. 2000;13:2-7.

12. Larone DH. Medically important fungi. A Guide to Identification 4th edn., ASM Press, Washington, USA, 2002; 221 p.

13. Schell WA, Salkin IF, McGinnis MR. Bipolaris, Exophiala, cedosporium, Sporothrix and other dematiaceous fungi. In: PR Murray (Ed.), Manual of Clinical Microbiology, ASM Press, Washington, USA, 2003;p. 18201847

14. Ellis MB. More Dematiaceous Hyphomycetes. CAB Press, Kew, England, UK, 1976; 507 p.

15. Di Giorgio C, Krempff A, Guiraud H, et al. Atmospheric pollution by airborne microorganisms in the city of Marseilles. Atmos. Environ. 1996;30(1):155-160. 